\title{
Penerapan Model Pembelajaran Think Pair Share dalam Meningkatkan Kemampuan Pemahaman Konsep Matematis pada Materi Garis dan Sudut
}

\author{
Lili Suryani A ${ }^{1}$, Ikram Hamid ${ }^{2}$, Ahmad Afandi ${ }^{3}$ \\ 1,2,3 Program Studi Pendidikan matematika, Universitas Khairun
}

\begin{abstract}
ABSTRAK
Penelitian ini bertujuan untuk mengetahui apakah terdapat peningkatan kemampuan pemahaman konsep matematis setelah diterapkannya model pembelajaran Think Pair Share (TPS) pada materi garis dan sudut siswa kelas VII MTs Negeri Dowora Kota Tidore Kepulauan semester genap tahun pelajaran 2015/2016.Jenis penelitian ini adalah jenis eksperimen. Dengan desain penelitian yaitu desain eksperimen pre-eksperimental design jenis one- shot case study.Populasi pada penelitian ini adalah siswa kelas VII Madrasah Tsanawiyah Negeri Dowora Kota Tidore Kepulauan dengan jumlah populasi 43 siswa. Adapun yang dijadikan sebagai sampel pada penelitian ini yaitu kelas VII A sebanyak 22 siswa yang akan diberi perlakuan model pembelajaran Think Pair Share (TPS). Untuk mengetahui apakah terdapat peningkatan kemampuan pemahaman konsep matematis setelah diterapkannya model pembelajaran Think Pair Share (TPS), data dianalisis dengan analisis inferensial yaitu menggunakan uji one sample t-test dengan bantuan SPSS 20. Dengan kriteria pengujian jika nilai signifikasi lebihdari 0,05 maka $\mathrm{H}_{0}$ diterima ditolak dan jika nilai signifikasi kurang dari 0,05 maka $\mathrm{H}_{0}$ ditolak diterima.

Hasil analisis data menunjukkan bahwa pada kelas eksperimen TPS pada variabel kemampuan pemahaman konsep matematis siswa dengan $\mathrm{Df}=23$ diperoleh nilai signifikansi $=0,035$. Nilai signifikansi pada variabel kelas eksperimen memiliki nilai yang kurang dari tingkat alpha 0,05 dimana hal inimenunjukkan bahwa ditolak dan diterima. Oleh karena diterima maka dapat disimpulkan bahwa pembelajaran dengan model TPS dapat meningkatkan kemampuan pemahaman konsep matematis siswa.
\end{abstract}

Kata kunci: Think Pair Share(TPS), kemampuan pemahaman konsep matematis. 


\section{PENDAHULUAN}

Pendidikan adalah pilar terpenting bagi tegaknya peradaban suatu bangsa. Namun kenyataannya strategi fungsional yang terjadi pada unsur-unsur pendidikan saat ini sangat lemah, yaitu lemahnya lembaga pendidikan yang tercermin dari kacaunya kurikulum, tidak optimalnya peran dan fungsi guru, tidak berjalannya proses belajar mengajar secara baik, kondisi pendidikan keluargyang tidak mendukung, dan keadaan masyarakat yang tidak kondusif. Akumulasi berbagai kelemahan itu menyebabkan tidak optimalnya pencapaian tujuan pendidikan yang diidealkan.Tujuan pendidikan yang hendak dicapai haruslah membutuhkan perbaikan pada unsur-unsur pendidikan.Maka untuk mencapai tujuan pendidikan yang diinginkan maka yang perlu dilakukan adalah penyiapan kurikulum yang paradigmatik, sistem pengajaran, sarana prasarana dan sumberdaya guru/dosen. Dengan demikian suatu bangsa akan menjadi bangsa yang berkembang dan maju (Yusanto dkk., 2014: 15).

Pada ilmu pendidikan, khususnya matematika terdiri atas bagian-bagian matematika yang dipilih guna menumbuh kembangkan kemampuan-kemampuan dan membentuk pribadi siswa serta berpadu dengan perkembangan IPTEK. Matematika merupakan disiplin ilmu yang mempunyai sifat khas jika dibandingkan dengan disiplin ilmu lain, karena pengetahuan matematika tidak dapat dipindahkan secara utuh dari pikiran guru ke pikiran siswa dalam menerima pelajaran. Pada diri siswa terjadi perubahan struktur kognitif, agar dapat memahami matematika tidak cukup hanya dengan menghafal rumus-rumus saja, tetapi membutuhkan pengertian, pemahaman, kreatifitas dan keterampilan secara mendalam dalam memahami matematika. Berdasarkan Undang-Undang Sisdiknas No. 20 Tahun 2003, pendidikan adalah usaha sadar dan terencana untuk mewujudkan suasana belajar dan proses pembelajaran agar peserta didik secara aktif mengembangkan potensi dirinya untuk memiliki kekuatan spiritual keagamaan, pengendalian diri, kepribadian, kecerdasan, akhlak mulia, serta keterampilan yang diperlukan dirinya, masyarakat, bangsa dan negara.

Pembelajaran di sekolah sangat diharapkan mampu mewujudkan suasana belajar yang dapat mengembangkan potensi-potensi siswa secara aktif.Agar hal itu dapat tercapai, pemahaman suatu konsep sangat penting diperlukan.Jika konsep dasar yang dimiliki siswa salah, maka sukar untuk memperbaiki kembali, terutama jika sudah diterapkan dalam menyelesaikan soal-soal matematika.Jika siswa bersifat terbuka masih ada harapan untuk memperbaikinya sebelum siswa menerapkannya dalam menyelesaikan soal-soal matematika. Namun jika siswa 
bersifat tertutup, maka kesalahan itu akan dibawa terus sampai pada suatu saat mereka menyadari bahwa konsep-konsep yang mereka miliki adalah keliru. Oleh karena itu yang terpenting adalah bagaimana siswa memahami konsep matematika secara utuh, sehingga jika diterapkan dalam menyelesaikan soal-soal matematika siswa tidak mengalami kesulitan.Gambaran permasalahan tersebut menunjukkan bahwa pembelajaran matematika perlu diperbaiki guna meningkatkan pemahaman siswa terhadap konsep-konsep matematika.Berdasarkan studi pendahuluan yang dilakukan peneliti pada tanggal 24 Maret 2016 di MTs.N Dowora, dengan menggunakan 3 soal berbentuk uraian, dapat diketahui bahwa kemampuan pemahaman konsep matematis masih rendah. Hat ini dapat dilihat pada diagram berikut:

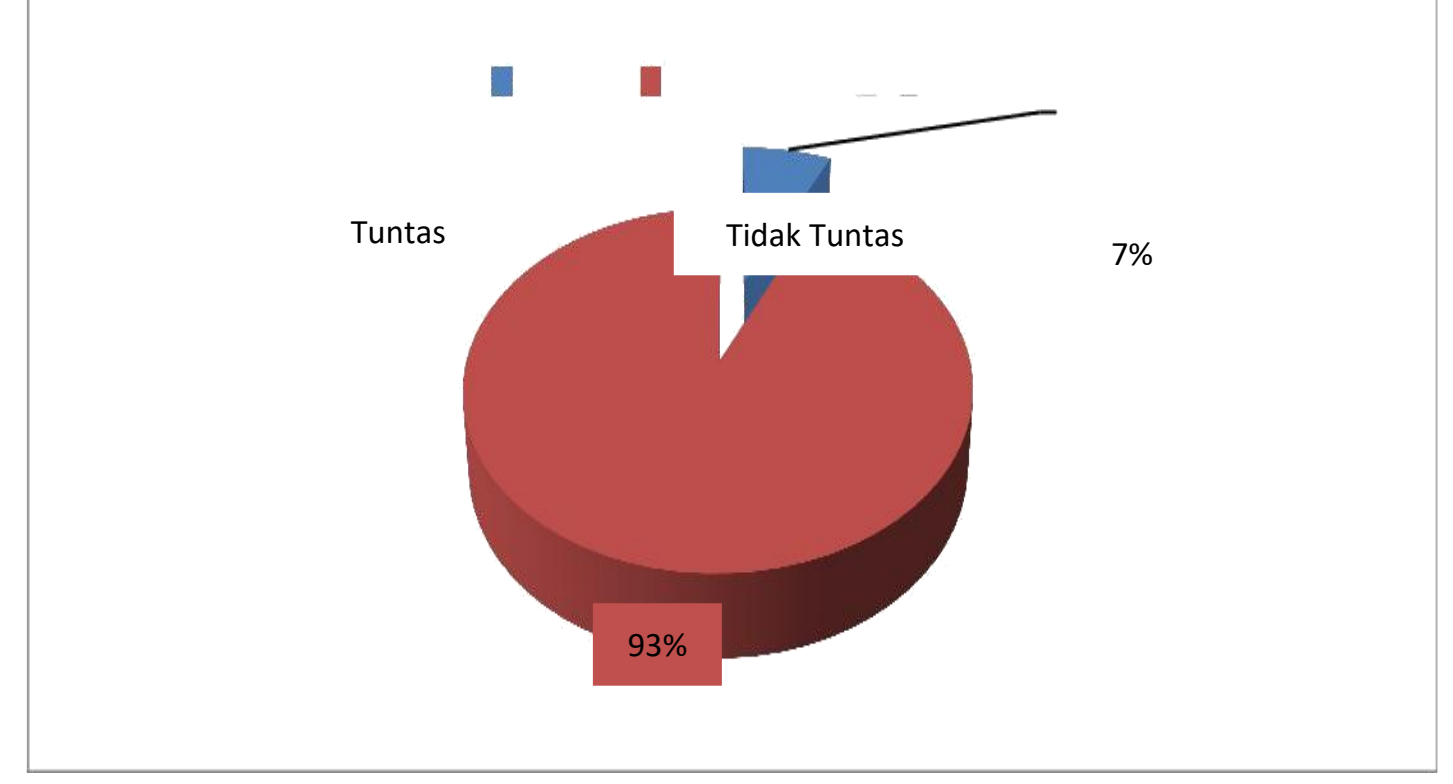

Gambar 1.Hasil pekerjaan siswa pada studi pendahuluan.

Diagram yang ditunjukkan di atas dapat diketahui bahwa dari 43 siswa hanya 3 orang yang dapat mencapai ketuntasan berdasarkan KKM yang di tentukan sekolah yaitu 62 . Terdapat 2 orang siswa yang tidak menjawab sama sekali dan 38 siswa lainnya menjawab dengan kurang tepat. Hal ini berarti bahwa sebagian besar siswa MTs.N Dowora kelas VII masih belum dapat menyelesaikan soal yang diberikan oleh gurunya dengan tepat dan benar.Dari jawaban yang diberikan para siswa dapat dilihat bahwa kemampuan pemahaman 
konsep matematis masih rendah, hal ini dapat dilihat dari indikator kemampuan pemahaman konsep yaitu menyatakan ulang konsep, mengklasifikasikan obyek menurut sifat-sifat tertentu dan mengaplikasikan konsep masih lemah.

Berdasarkan wawancara dengan guru bidang studi matematika sebagaimana terlampir, rendahnya kemampuan pemahaman konsep matematis siswa ini disebabkan oleh beberapa faktor diantaranya siswa cenderung menghafal dan kurang memahami soal yang diberikan, sehingga siswa merasa kesulitan ketika menyelesaikan soal-soal yang bervariasi bentuk dan permasalahannya.Ini disebabkan siswa memandang pelajaran matematika adalah pelajaran yang sulit dan membosankan, padahal matematika adalah salah satu mata pelajaran yang menduduki peran penting dalam pendidikan karena dilihat dari waktu yang digunakan dalam pelajaran matematika disekolah, lebih banyak dibandingkan dengan mata pelajaran lainnya. Berdasarkan penelitian yang dilakukan oleh Ratu (2013) pada SMP Negeri 1 Merbau Mataram tahun pelajaran 2012/2013, menunjukkan bahwa pembelajaran kooperatif tipe TPS dapat meningkatkan pemahaman konsep matematis siswa kelas VII semester genap SMP Negeri 1 Merbau Mataram tahun pelajaran 2012/2013. Pembelajaran kooperatif merupakan suatu model pembelajaran yang mengutamakan adanya kerjasama, yakni kerjasama dalam berkelompok untuk mencapai tujuan pembelajaran.Dalam pembelajaran kooperatif terdapat berbagai tipe pengajaran, salah satunya adalah Think Pair Share (TPS).

TPS merupakan suatu teknik pembelajaran yang sederhana dengan keuntungan yang dapat meningkatkan kemampuan siswa dalam mengingat suatu informasi.TPS juga merupakan salah satu metode pengajaran yang dapat digunakan untuk membuat variasi suasana pola diskusi kelas. Seorang siswa juga dapat belajar dari siswa lain serta saling menyampaikan idenya untuk didiskusikansebelum disampaikan di depan kelas dan selain itu siswa juga dihadapkan pada masalah-masalah nyata yang ada di lingkungan serta mengajarkan mereka berdiskusi atau belajar secara berkelompok. Aktivitas belajar siswa khususnya aktivitas mental siswa dapat teramati oleh guru. Berdasarkan penjelasan di atas, penerapan model pembelajaran kooperatif tipe TPS diasumsikan dapat meningkatkan kemampuan pemahaman konsep matematis siswa, karena model pembelajaran koopertaif tipe TPS dapat menciptakan situasi dan kondisi belajar yang dapat melatih siswa menemukan dan memahami konsep matematis. 


\section{METODOLOGI PENELITIAN}

Penelitian ini dilaksanakan di kelas VII Madrasah Tsanawiyah (MTs) Negeri Dowora Kota Tidore Kepulauan pada tanggal 23-28 Mei 2016.Jenis penelitian yang digunakan dalam penelitian ini adalah jenis eksperimen. Dengan desain penelitian yaitu desain eksperimen preeksperimental design jenis one-shot case study. Adapun populasi dari penelitian ini adalah 43 siswa dari kelas VIIA dan VII B Madrasah Tsanawiyah (MTs) Negeri Dowora Kota Tidore Kepulauan.Sampel penelitian ini yaitu kelas VII A yang berjumlah 24 siswa. Pengambilan sampel ini dengan carasimple random sampling yaitu pengambilan anggota sampel yang dilakukan secara acak tanpa melihat strata yang ada dalam populasi.

Dalam penelitian ini, variabel dependent (variabel terikat) adalah kemampuan pemahaman konsep matematis dan variabel independent (variabel bebas) adalah model pembelajaran kooperatif tipe Think Pair Share (TPS).Teknik pengumpulan data yang digunakan dalam penelitian ini yaitu teknik tes.Teknik tes pada penelitian ini adalah posttest.Posttest digunakan untuk mengumpulkan data tentang aspek kemampuan pemahaman matematis siswa.Adapun tes yang digunakan adalah bentuk essai dengan materi garis dan sudut.Sebelum digunakan untuk posttest soal-soal tersebut di uji coba terlebih dahulu. Penelitian ini menggunakan analisis inferensial untuk menjawab rumusan masalah yakni untuk mengetahui apakah terdapat peningkatan kemampuan pemahaman konsep matematis siswa setelah diterapkan model pembelajaran think pair share (TPS) yang menggunakan uji one sample t-test, namun sebelumnya harus melalui uji prasyarat yakni uji normalitas.

\section{HASIL PENELITIAN}

Penelitian ini dilaksanakan dengan tujuan untuk mengetahui ada tidaknya peningkatan kemampuan pemahaman konsep matematis setelah diterapkannya model pembelajaran TPS pada materi garis dan sudut siswa kelas VII MTs Negeri Dowora Kota Tidore Kepulauan semester genap tahun pelajaran 2015/2016.Penelitian ini diadakan di MTs Negeri Dowora Kota Tidore Kepulauan dengan 24 siswa sebagai sampel.Data yang diperoleh dari hasil penelitian ini berupa dataposttest dari kelas VII A. Data posttest merupakan hasil dari pembelajaran TPSyang diterapkan. Data dari posttest diperoleh nilai minimum 35,4, nilai maksimum 93,75. Sedangkan nilai rata-rata 69,57, dan standar deviasi 16,62. 
Data yang digunakan pada analisis statistik inferensial ini adalah data yang diperoleh dari kelas VII A setelah perlakuan.Data setelah perlakuan digunakan untuk melakukan pengujian hipotesis, yaitu mengetahui adanya peningkatan kemampuan pemahaman konsep matematis setelah diterapkan model pembelajaran TPS.Pengujian persyaratan analisis data yakni uji normalitas. Uji normalitas dilakukan dengan menggunakan program SPSS 20. Hasil uji normalitasdata setelah perlakuan disajikan pada tabel berikut.

Tabel 5

Hasil uji normalitas setelah perlakuan

\begin{tabular}{|c|c|c|}
\hline Kelas Eksperimen & Variabel & Signifikansi \\
\hline Model TPS & Kemampuan pemahaman konsep matematis & 0,085 \\
\hline
\end{tabular}

Pada tabel di atas menunjukkan bahwa nilai signifikansi data posttest lebih besar dari 0,05 (sig. >0,05) sehingga Ho diterima. Oleh karena Ho diterima maka dapat disimpulkan bahwa data berasal dari populasi yang berdistribusi normal.

Uji hipotesis peningkatan kemampuan pemahaman konsep matematis setelah diterapkannya model pembelajaran TPS dilakukan dengan one sample t-test.Uji ini dilakukan untuk mengetahui adanya peningkatan kemampuanpemahaman konsep matematis setelah diterapkannya model pembelajaran TPS.Hasil uji one sample t-test untuk model pembelajaran TPS disajikan pada tabel berikut.

\section{Tabel 6}

Hasil uji hipotesis kemampuan pemahaman konsep matematis setelah perlakuan

\begin{tabular}{|c|c|c|c|}
\hline Variabel & $\begin{array}{c}\text { Kelas } \\
\text { eksperimen }\end{array}$ & Df & signifikansi \\
\hline Kemampuan pemahaman matematis & Model TPS & 23 & 0,036 \\
\hline
\end{tabular}

Berdasarkan data yang disajikan pada tabel di atas diketahui bahwa pada kelas eksperimen TPS pada variabel kemampuan pemahaman konsep matematis siswa dengan Df = 23 diperoleh nilai signifikansi $=0,035$ artinya 95\% dipercaya keputusan hipotesis yang akan disimpulkan. Nilai signifikansi pada variabel kelas eksperimen memiliki nilai yang kurang dari tingkat alpha 0,05 dimana hal ini menunjukkan bahwa Ho ditolak dan H1 diterima. Oleh 
karena H1 diterima maka dapat disimpulkan bahwa pembelajaran dengan model TPS dapat meningkatkan kemampuan pemahaman konsep matematis siswa.

\section{PEMBAHASAN}

Pada penelitian ini, peneliti menerapkan model pembelajaran TPS.Peneliti memberikan materi pembelajaran garis dan sudut kemudian membagi siswa dalam enam kelompok yang setiap kelompok terdiri dari empat orang.Model pembelajaran TPS memuat tiga langkah utama yaitu think, pair dan share.

Pada tahap think, peneliti membagikan LKS dan mengajak setiap anggota kelompok berpikir untuk menemukan penyelesaian masalah yang ada pada LKS.Selanjutnya pada tahap pair (berpasangan), kelompok membentuk anggota-anggotanya secara berpasangan dan kemudian berdiskusi mengenai penyelesaian yang telah ditemukan. Pada tahap share (berbagi) siswa mendiskusikan hasil pemikirannya kepada kelompoknya. Selanjutnya siswa mempresentasikan hasil diskusinya di depan kelas. Guru meminta perwakilan beberapa kelompok untuk mempresentasikannya di depan kelas.

Usaha siswa untuk memahami masalah matematika dapat terlihat pada tahap think (berpikir) ini dengan waktu 15 menit yang diberikan. Selanjutnya untuk menambah dan memperkuat pemahaman siswa, pada tahap pair (berpasangan) siswa kembali mendiskusikan hasil pemikirannya kepada pasangannya dengan waktu 10 menit yang diberikan. Selanjutnya siswa berbagi hasil diskusinya kepada kelompoknya pada tahap share (berbagi) agar dapat menambah pemahaman siswa. Setiap kelompok lalu diminta oleh peneliti untuk mempresentasikan hasil diskusinya di depan kelas. Dari hasil LKS yang telah diselesaikan setiap kelompok, diperoleh tiga kelompok yang dapat menyelesaikan 4 soal dalam LKS dengan benar dan tiga kelompoknya hanya dapat menyelesaikan 2 soal LKS dengan benar.

Pada pertemuan berikutnya, siswa diminta untuk menyelesaikan soal tes akhir atau posttest berupa soal esay sebanyak 5 soal.Setiap soal memuat satu indikator kemampuan pemahaman konsep matematis. Adapun indikator yang digunakan pada soal tes akhir yaitu: (1) menyatakan ulang sebuah konsep, (2) mengklasifikasikan objek-objek menurut sifat-sifat tertentu, (3) menyajikan konsep dalam berbagai bentuk representasi matematis, (4) menggunakan, memanfaatkan, dan memilih prosedur atau operasi tertentu, serta (5) mengaplikasikan konsep. Adapun soal posttest sebagai berikut 


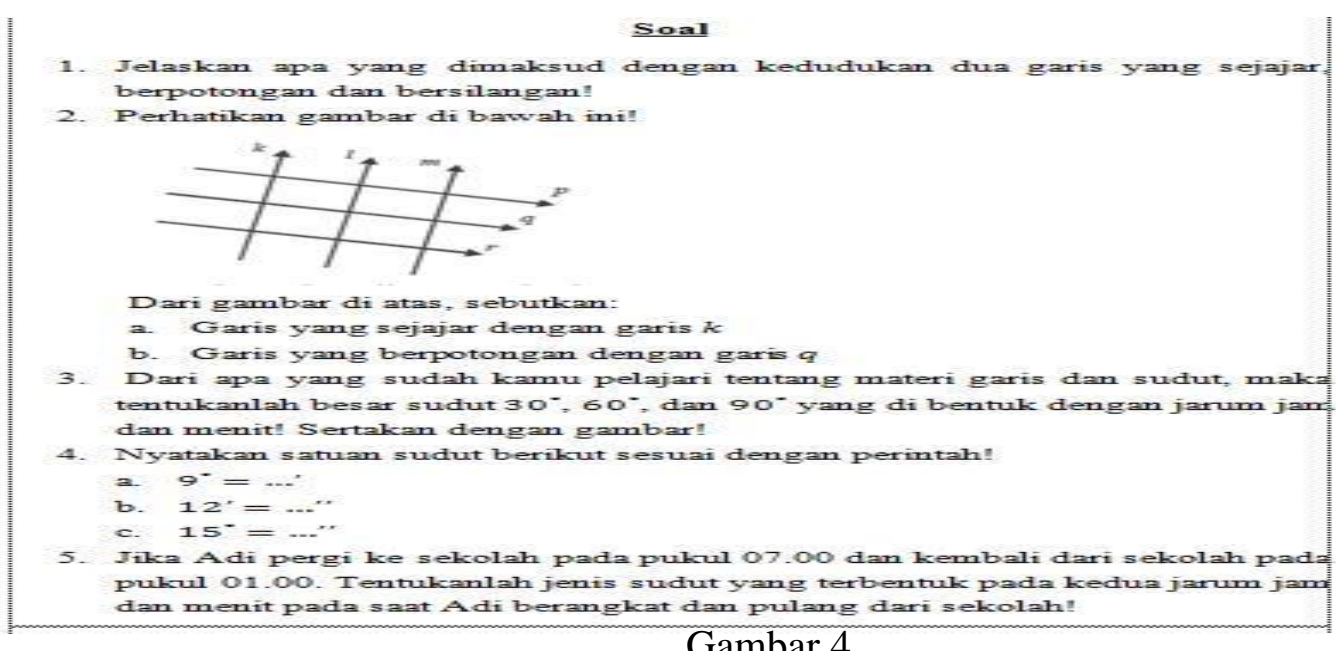

\section{Gambar 4}

Soal Posttest

Siswa dapat tekategori tuntas atau memiliki kemampuan pemahaman konsep matematis yang baik jika hasil tes yang diperoleh lebih dari KKM yang ditentukan yaitu 62.Hasil yang diperoleh pada tes akhir adalah sebanyak 17 siswa yang dapat mencapai KKM dan 7 siswa lainnya tidak mencapai KKM.Berikut hasil pekerjaan siswa yang tuntas berdasarkan KKM.

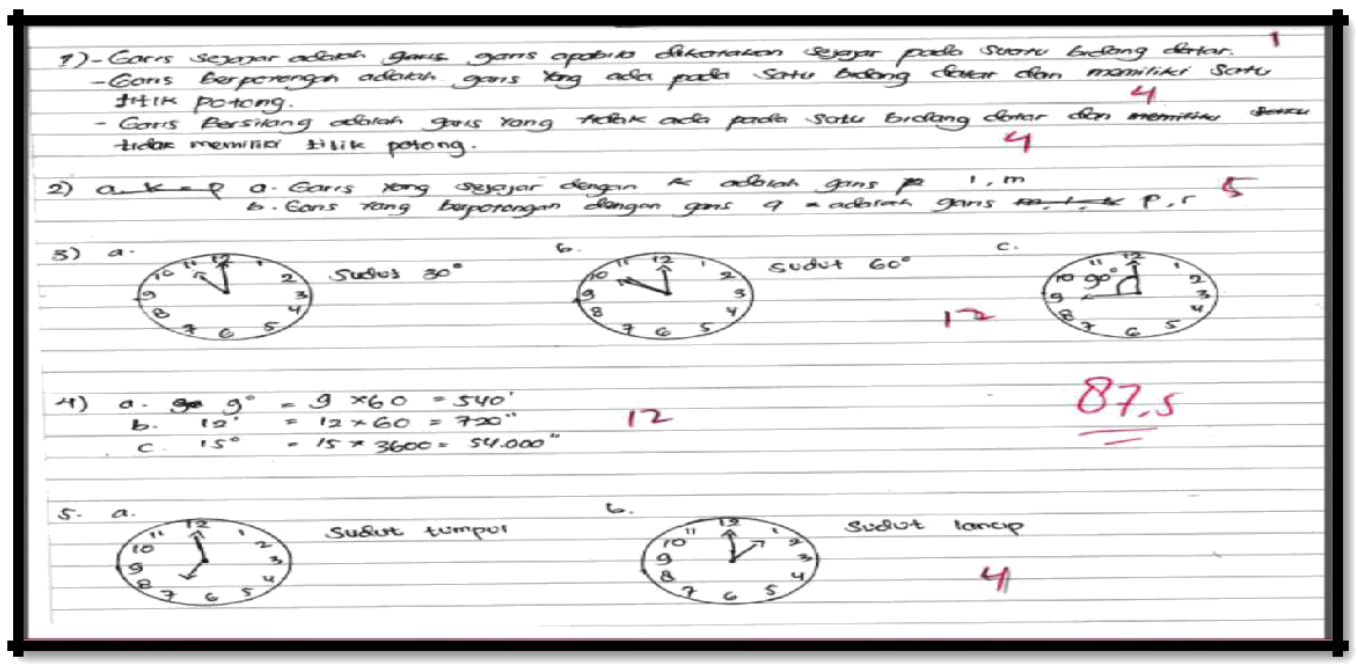

Gambar 5

Hasil kerja siswa yang tuntas berdasarkan KKM

Gambar 5 di atas menunjukkan siswa dapat memahami materi dengan baik dan dapat menjawab soal dengan benar walaupun belum sempurna.Dari hasil di atas siswa dapat 
menyatakan ulang konsep dengan benar walaupun belum sempurna.Pada hasil nomor 2 siswa dapat mengklasifikasikan objek-objek menurut sifat-sifat tertentu walaupun belum sempurna.Pada hasil nomor 3 siswa dapat menyajikan konsep dalam bentuk representatif matematis dengan benar.Pada hasil nomor 4 siswa dapat menggunakan, memanfaatkan dan memilih prosedur atau operasi tertentu dengan benar.Pada soal nomor 5 siswa dapat mengaplikasikan konsep dengan benar.Setiap jawaban yang benar diberikan skor 4 berdasarkan rubrik.Hal ini berarti siswa telah memiliki kemampuan pemahaman konsep matematis berdasarkan indikator-indikator yang dimiliki.

Secara keseluruhan penggunaan model pembelajaran TPS dapat meningkatkan pemahaman matematis siswa. Hal ini terlihat pada saat penelitian kemampuan bekerja sama berkembang dengan baik sehingga siswa yang telah memahami soal matematika dapat membantu memahamkan siswa yang belum paham. Selain itu, dalam penelitian ini siswa dapat mempresentasikan kembali dengan benar konsep matematika yang diperoleh dari hasil diskusinya.Hasil studi ini sejalan dengan hasil penelitian Budiarto (2013) yang menyatakan bahwa model pembelajaran Think Pair Share dapat meningkatkan pemahaman konsep matematika siswa melalui kemampuan siswa dalam menerapkan konsep dengan benar. Peningkatan kemampuan pemahaman konsep matematis siswa melalui penerapan model pembelajaran Think Pair Share pada penelitian ini dapat dilihat pada hasil yang diperoleh pada tes akhir yaitu sebanyak $70 \%$ siswa dapat menjawab soal-soal yang memuat 4 indikator kemampuan pemahaman konsep matematis dengan benar. Sehingga dapat dikatakan bahwa semua indikator penelitian mulai dari kemampuan menyatakan ulang sebuah konsep, mengklasifikasikan objek-objek menurut sifat-sifat tertentu, menyajikan konsep dalam bentuk representatif matematis dengan benar, menggunakan, memanfaatkan, dan memilih prosedur atau operasi tertentu, serta kemampuan menerapkan konsep sudah tercapai.

\section{KESIMPULAN}

Berdasarkan hasil analisis data dan pembahasan bahwa dapat diambil kesimpulan bahwa model pembelajaran kooperatif tipe Think Pair Share (TPS) dapat meningkatkan kemampuan pemahaman konsep matematis pada materi garis dan sudut di kelas VII Madrasah Tsanawiyah (MTs) Negeri Dowora Kota Tidore Kepulauan. 


\section{DAFTAR PUSTAKA}

Arnidha, Yunni. 2013. Efektifitas Model Kooperatif Tipe Think Pair Shareterhadap kemampuan Pemahaman Konsep dan Disposisi Matematika Siswa. Tesis, Universitas Terbuka Jakarta, Jakarta.

Anwar, Nevi Trianawaty. 2016. Perbandingan Model Pembelajaran LearningCycle 5e dan Problem Based Learning (PBL) ditinjau dari Hasil Belajar Siswa pada Materi Statistika di SMP Negeri 6 Kota Ternate. Skripsi,Universitas Khairun, Ternate.

Budiarto, Fitriyanto Wisnu. 2013. Peningkatan Pemahaman Konsep MatematikaMenggunakan Model Pembelajaran Think Pair Share (TPS) Materi Pangkat Tak Sebenarnya. Skripsi, Universitas Muhammadiyah Surakarta,Surakarta.

Chusna, Rifngatul. 2014. Pengaruh Penggunaan Model Pembelajaran KooperatifTipe TPS ( Think Pair Share ) terhadap Kreatifitas Berpikir Siswa dalam Menyelesaikan Masalah Matematika Materi Logika Matematika Pada Siswa Kelas X MAN Tulungagung. Skripsi, IAIN Tulungagung, Tulungagung.

Depdiknas. 2003. Undang-Undang RI Nomor 20, Tahun 2003,tentang Sistem Pendidikan Nasional.

Fransiska, Arina. 2012. Pengaruh Model Pembelajaran Think Pair Share (TPS)terhadap Pemahaman Konsep pada Pelajaran Matematika di Kelas VII SMP Negeri 12 Palembang. Skripsi, Universitas Negeri Sriwijaya,Palembang.

Gunawan, Muhammad Ali. 2013.Statistika untuk PenelitianPendidikan.Yogyakarta: Parama Publishing.

Muhlisin. 2013. Keefektifan Pembelajaran Model TPS BerbantuanGeometer'sSketchpad pada Pencapaian Kemampuan Pemecahan Masalah MateriSegitiga Kelas VII. Skripsi, Universitas Negari Semarang, Semarang.

Maumbu, Sri Multina., Ismail, Sumarno,., dan Yahya, Lailany. 2013. Deskripsi Pemahaman Konsep Bentuk Aljabar dalam Mind Mapping Siswa Kelas VII SMP N 3 Gorontalo.Jurnal Pendidikan UNG, Vol (1), 1-10.

Rizqiana, Novia. 2013. Pengaruh Strategi Pembelajaran PQ4R TerhadapPemahaman Matematika Siswa SMP Negeri 6 Kota Cirebon.Skripsi,IAIN Syekh Nurjati Cirebon, Cirebon.

Rusmin. 2012. Model-model Pembelajaran. Jakarta: RajaGrafindo Persada.

Ratu, A.M., Coesamin, A,., dan Djalil, A. 2013. Pengaruh Model Pembelajran Kooperatif Tipe Think Pair Share terhadap Pemahaman Konsep Matematis siswa.Jurnal Pendidikan Matematika Unila, Vol (1), 2-9. 
Sugiyono. 2011. Metode Penelitian Kuantitatif, Kualitatif dan R\&D. Bandung:Alfabeta.

Sudjana. 2005. Metode statistika. Bandung: Tarsito.

Verowita, Winda., Murni, Dewi., dan Mirna. 2012. Pengaruh Penerapan Model Pembelajaran Kooperatif Tipe Think pair share terhadap Pemahaman Konsep dalam Pembelajaran Matematika. Jurnal Pendidikan Matematika, Vol (1), 48-51.

Yusanto, Ismail. dkk. 2014. Menggagas Pendidikan Islami. Bogor: Al Azhar Press. 